\title{
Participatory Budgeting as a Method for Improving Public Spaces in Major Polish Cities
}

\author{
A. Szczepańska ${ }^{1}$ (D) $\cdot$ M. Zagroba ${ }^{1}$ (D) $\cdot$ K. Pietrzyk ${ }^{1}$ (D)
}

Accepted: 19 October 2021 / Published online: 1 November 2021

(c) The Author(s) 2021

\begin{abstract}
One of the forms of public participation in the local governance system is civic budgeting which actively engages residents in developing projects and voting on the submitted proposals. Civic budgeting aims to involve local communities in deciding how a defined portion of public resources should be allocated by means of a democratic debate. Public spaces are the essence of urban life; therefore, the aim of the study was to analyze civic budget records relating to public spaces. The study was conducted in the largest Polish cities. The research involved quantitative and comparative analytical methods. The analysis focused on community involvement and local community needs, represented by a wide array of public space-related project categories. The analyzed cities were ranked according to their civic engagement, and the resulting classification was compared with voter turnout during polls on the proposals adopted as part of the CB process. The results revealed considerable diversity in both civic engagement and local needs, and they could be used to develop guidelines for designing public spaces in the urban planning process. The present findings are also a valuable source of information for local governments in their efforts to improve the functioning, attractiveness and development of user-friendly spaces in citizenoriented cities.
\end{abstract}

Keywords Citizen-oriented cities · Public participation · Civic budget · Public spaces

A. Szczepańska

aszczep@uwm.edu.pl

M. Zagroba

mazag@uwm.edu.pl

K. Pietrzyk

katarzyna.pietrzyk@uwm.edu.pl

1 Department of Socio-Economic Geography, Institute of Spatial Management and Geography, Faculty of Geoengineering, University of Warmia and Mazury in Olsztyn, Prawocheńskiego 15, 10-724 Olsztyn, Poland 


\section{Introduction}

Urban space, including public spaces, is shaped not only by administrative decisions, but also by the residents. Any community inhabiting and functioning within a specific urban unit should be able to voice their opinions on how public spaces should be organized in order to meet their needs and expectations. This is a very important element of social life in cities because a wide range of human needs and aspirations can be fulfilled through urban planning as well as architectural and functional solutions. These include developing a sense of belonging and attachment to one's place of residence, as well as a feeling of responsibility for that place. The residents can influence the way their city is managed and improved by means of social dialogue with the urban authorities. Their opinions and insights play an important role in the process of changing and enhancing the attractiveness of different parts of the city. Social dialogue can assume many forms, including civic budgeting (CB). The first civic budget was introduced in the late 1980s. Since then, the idea evolved significantly and diffused to many countries including Poland, where it was implemented for the first time in 2011 (Niklewicz, 2014).

Public spaces are the essence of urban life, and an analysis of local needs concerning public spaces can facilitate the identification of the directions and scope of the required changes to improve the quality of local life. Therefore, the main objective of this study was to analyze civic budget records concerning public spaces in the largest Polish cities. The research hypothesis states that the results of the analysis can be used to evaluate urban communities' involvement in local affairs and to identify the main problems faced by the local residents. The analysis focused on local community engagement in terms of the number of cast votes, as well as the value of funds allocated to public space projects. The local communities' needs and aspirations were analyzed by identifying spatial components and functionalities that were most often proposed for $\mathrm{CB}$. These proposals indicate that local residents feel responsible for their place of residence and neighborhood and that they value public spaces that are user-friendly and functional. The analyzed cities were ranked according to their civic engagement, and the resulting classification was compared with the results of CB analyses.

\subsection{Civic Participation}

Civic participation is a form of active social involvement in the process of making decisions that affect the daily lives of local communities. Local residents actively participate in the establishment and operations of civic groups and non-governmental organizations; they are involved in the decision-making process, as well as social, public and political affairs (Oh et al., 2019; Szarek-Iwaniuk et al., 2020). Civic participation contributes to the evolution of local social potential and social capital (Barnes et al., 2003). It enables local community members to express their opinions and views, and, consequently, to work out a compromise in the pursuit of the common good.

Two types of participation can be identified: horizontal participation that involves engagement with the local community, and vertical participation that involves personal engagement with the state. Horizontal participation relies on the efforts made by various social groups in the pursuit of a common goal. In turn, vertical participation engages citizens in activities that are initiated by the public authorities. These measures involve 
various types of activities, including public activities initiated by the citizens, engagement of community members, or voting in elections (Olejniczak, 2015).

Civic participation activities are undertaken for various reasons. They contribute to the development of democracy and integrate local communities through shared decision-making. Civic participation is also an effective problem-solving strategy because it provides all stakeholders with an opportunity to voice their opinions. It enables community members to resolve conflicts and achieve compromise on local matters (Mohammadi et al., 2018).

\subsection{Civic Budgeting}

Civic budgeting is a form of public participation which enables communities to join in the decision-making processes and promotes active public engagement in local affairs. For this reason, in some countries, $\mathrm{CB}$ is also referred to as participatory budgeting (Sintomer et al., 2012). According to the UN “...in general terms, a Participatory Budget is "a mechanism (or process) through which the population decides on, or contributes to decisions made on, the destination of all or part of the available public resources." (UN-HABITAT, 2004 p.11). Hence it can be defined as "a mechanism of resource allocation that transfers decision-making power over the capital expenditure portion of the municipal budget from the city council to public assemblies" (Walker, 2016 p.58), or as "... a democratic process in which members of a community determine how to spend governmental funds" (Augsberger et al., 2017 p. 243). A similar definition of CB was offered by Janiszek and Majorek (2017) who observed that this process involves the allocation of a portion of public funds to local needs by means of a democratic debate. This process is consistent with the mechanism of co-governance, namely governance in ongoing cooperation with various social partners (Sobol, 2017). The participation of the local community in the process of earmarking a portion of public funds is central to this concept, as underlined in each of the definitions cited above. As a result, $\mathrm{CB}$ has become a popular form of cooperation geared towards improving the quality of local governance (Cabannes, 2004; Kębłowski, 2014; Gawroński, 2015; Džinić et al., 2016; Gómez et al., 2016; Kamrowska-Zaluska, 2016; Rondinella et al., 2017; Mannarini \& Fedi 2018; Bartocci et al., 2019).

The CB concept has spread to many countries across the world (Aleksandrov et al., 2018; Falanga \& Lüchmann, 2020; Goldfrank, 2007; Lin \& Chen, 2020; No \& Hsueh, 2020; Pinnington et al., 2009; Röcke, 2014; Schneider \& Busse, 2019; Švaljek et al., 2019; Uddin et al., 2019). The first CB projects in Poland were implemented in 2011. Currently, several hundred Polish cities are running CB-related projects. Poland is one of the few countries where participatory budgets are prescribed by law (Sześciło, 2015; TykwińskaRutkowska \& Glejt 2015; Kersting et al., 2016). Pursuant to the Act of 11 January 2018 amending certain laws to increase citizens' participation in the process of electing, operating and controlling selected public bodies (Journal of Laws of 2018, item 130, as amended), CB is interpreted as a specific form of public consultation. By participating in a $\mathrm{CB}$ process, residents decide in a poll how to spend a part of the annual municipal budget. The projects selected by public voting as part of participatory budget are then included in a municipality's budget resolution. In municipalities that are cities with county status (urban counties), a participatory budget process is mandatory, and the allocated budget has to account for minimum $0.5 \%$ of total municipal expenditures posted in the last report on the implementation of the municipal budget. Projects submitted for participatory budgeting may have a local character, and they can apply to auxiliary units within a city's administrative structure and its inhabitants (such as housing estates and districts), or they can cover 
the entire city (projects that cover more than one auxiliary unit and generate benefits for the majority of urban residents). In Poland, the value of the funds allocated to the implementation of civic budgets for a given year (which rarely exceed $1 \%$ of the city's budget) is set by the local authorities, whereas the projects to be financed from the allocated funds are selected by the residents. Civic budgeting has a clear advantage over other instruments of public participation in that it promotes collaborative decision-making. Local authorities guarantee that the outcome of the voting process will be legally binding and approved, which provides citizens with real decision-making powers in a city's financial affairs (Martela, 2013; Boryczka, 2015). However, the evaluation of the submitted proposals may be problematic because the ranking methods do no employ quantitative assessment criteria (Wilczak and Rutkowska, 2017). According to Sobol (2017), another important advantage of the $\mathrm{CB}$ procedure is that it opens a civil dialogue. A civic budget has to reconciliate the diverse opinions and needs of the local residents, NGOs and local government representatives, whereas proposals are submitted and selected during a public vote. All residents with active voting rights are eligible to cast votes in this process (Słomczewska, 2013). Civic budgets are implemented by a growing number of cities each year (Sobol, 2017), which indicates that citizens are increasingly willing to exercise their right to vote.

Civic budgeting is an effective instrument for promoting civic activism, and it is an educational tool that shapes awareness, supports citizen engagement in local matters, and boosts citizenship (Radziszewski, 2016). Social participation involves integrated city management and public involvement in the co-development of civic budgets; it is inextricably linked with social communication and represents a higher level of cooperation between citizens and the authorities (Basaj, 2013). However, the CB process is not free of weaknesses, some of which stem from mistrust. Baiocchi and Ganuza (2014) have argued that the implementation of a participatory budget may be opposed by the councilors themselves in fear of having their authority undermined and being sidelined in the decision-making process. The role of NGOs as representatives of public interests could also become diminished as citizens are provided with access to instruments of participatory budgeting, such as voting, which can influence the decision-making process (Bherer et al., 2016; Ganuza et al., 2014). In some cases, civic budgets remain a political promise which never materializes. This poses one of the greatest threats to civic engagement because the local authorities merely pretend to be engaged in local affairs, whereas the implemented measures largely neglect local needs (Sintomer et al., 2012).

In Poland, there are no legal restrictions regarding the type of projects that can be included in $\mathrm{CB}$, and residents can theoretically vote on all matters covered by the local legislation at the level of governance where the CB process is implemented (Kraszewski \& Mojkowski, 2014). Therefore, the proposals submitted for participatory budgeting relate to various types of development projects, most of which pertain to public spaces that are inherently linked with urban space. These spaces have been deeply ingrained into the public consciousness, and the residents are able to select key areas that require esthetic and functional improvement (Chruściński et al., 2014). In many cases, priority is given to projects relating to spatial planning, urban green spaces, improvement or expansion of public utilities, sports facilities, recreational sites, culture and entertainment venues.

\subsection{Public Spaces}

Public spaces are integral elements of the urban fabric which are responsible for the form and structure of cities (Lynch, 2011). Despite the fact that public spaces are a special 
category of urban spaces, they constitute space in the conventional sense (Dymnicka, 2013). Regardless of the size of an urban system, public spaces share universal characteristics, such as the presence of a main street with commercial functions and a municipal square with various attractions (Lorens et al., 2010). The public space concept is rich in meaning and diversity, but what differentiates public spaces from other types of space is that they are open to the general public and that they promote communication and interactions between individuals and social groups. Public spaces are regarded as open spaces and meeting places that foster the exchange of ideas (Coarelli, 1982).

Public spaces are unique in that they cater to diverse local needs, both material and non-material, and create a platform for social integration. For this reason, public spaces play an important role in the functioning of cities and deliver various benefits for individuals and communities (Benita et al., 2019; Gehl, 2011; Koohsari et al., 2015; Mews et al., 2018; Pasaogullari \& Doratli, 2004; Thompson, 2002; Wood et al., 2017). The key benefits include improved physical and mental health, social interactions, integration of the local community, socialization and social stimulation, improved quality of life, as well as the feeling of responsibility for one's place of residence (Madanipour, 1999; Tolstykh, 2016). Therefore, public spaces promote human contact and breathe life into cities. Public spaces are venues where authentic community life can be experienced and where a city's image and identity are shaped.

Public spaces generally attract considerable interest from both the authorities and local residents. Most city residents are aware of the positive impact of well managed public spaces, and they become actively involved in the process of creating participatory budgets to shape their immediate environment. Therefore, adequate management of public spaces is key to meeting local needs because it strengthens the residents' sense of attachment and the feeling of responsibility for the quality and functionality of the surrounding space.

\section{Materials and Methods}

\subsection{Description of the Research Object}

Civic budgets were analyzed in the capital cities of Polish voivodeships. The three-tier administrative (territorial) division of Poland was introduced on 1 January 1999, and the territory of Poland was divided into voivodeships, counties and municipalities. According to the Classification of Territorial Units for Statistics, voivodeships fall into the NUTS 2 category. Poland has 16 voivodeships with 18 capital cities which are the largest Polish cities. Two voivodeships have two capitals each: Bydgoszcz and Torun in the KuyavianPomeranian Voivodeship, Gorzów Wielkopolski and Zielona Góra in the Lubusz Voivodeship. Warsaw is the capital of Poland. The boundaries, names and main administrative centers of Polish voivodeships are presented in Fig. 1.

In 2019 , the analyzed cities had a combined population of 7,735,854, which accounted for $33 \%$ of Poland's urban population and $20 \%$ of Poland's total population. The analyzed cities include metropolitan areas as well as cities of regional significance. The evaluated cities differ in the rate of development and local influence, but all of them are all important administrative, business, service, research, education and healthcare centers, and important transport hubs (Komorowski, 2012; Sokołowski, 2011; Rokita-Poskart, 2016; Jurkowski, 2018; Garbzaz et al., 2020). A general description of the analyzed urban centers is presented in Table 1 . 


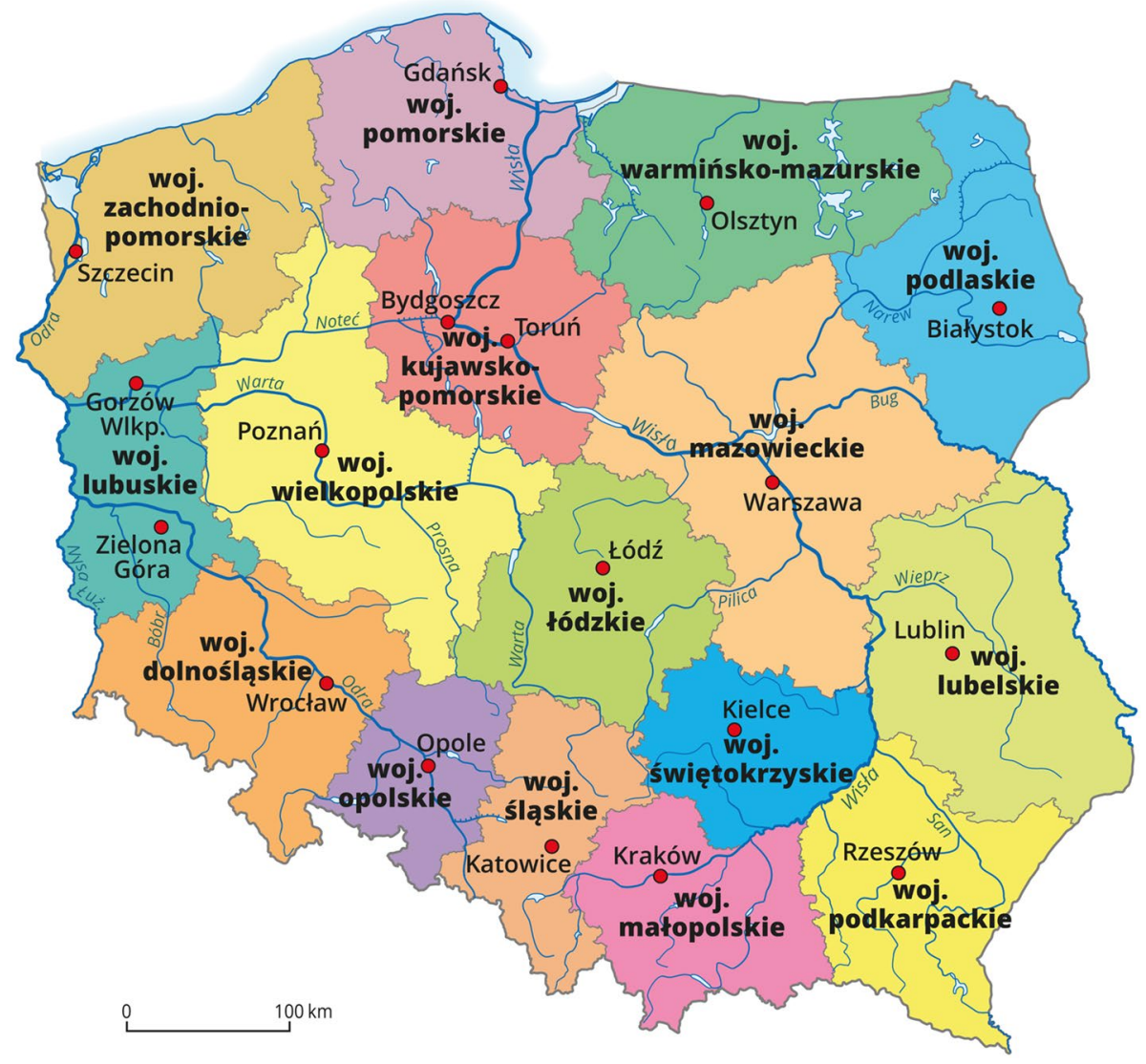

Fig. 1 Administrative division of Poland-voivodeships and their capital cities. Source: Educational platform of the Ministry of Education and Science https://epodreczniki.pl/

\section{Research Methodology}

The analysis was based on the information concerning civic budgets and voting results for 2019 published by 18 major Polish cities. The projects approved for development were analyzed in detail to identify proposals relating to public spaces. The main emphasis was placed on projects targeting urban greens, sports and recreation facilities, playgrounds, spaces designated for revitalization, culture and entertainment centers, technical infrastructure (transport, lighting, surveillance), land management and upgrading, and animal care. A wide variety of projects targeting culture and entertainment centers was submitted in the surveyed cities, including the organization of outdoor events such as concerts, festivals or shows in public spaces, as well as other projects, such as workshops, courses or purchase of books for public libraries. Some projects in the animal care category also focused on facilities in public spaces, including the installation of nesting boxes for birds and clean-up facilities for dog owners. Other initiatives, such as financial assistance for animal shelters, were unrelated to public spaces. For this reason, some analyses involved both categories of projects, whereas only one category was considered in other analyses. 
Table 1 Characteristics of the capital cities of Polish voivodeships. Source: Local Data Bank (2018) and Quality of life ranking (2018)

\begin{tabular}{|c|c|c|c|c|}
\hline City & Population & $\begin{array}{l}\text { Unemployment } \\
\text { rate }\end{array}$ & $\begin{array}{l}\text { Per capita income } \\
\text { in } 2019\end{array}$ & $\begin{array}{l}\text { Life quality index } \\
{[\max .100 \mathrm{pts}]}\end{array}$ \\
\hline Białystok & 297,554 & 5.4 & 7295.32 & 71.78 \\
\hline Bydgoszcz & 348,190 & 2.9 & 6799.21 & 55.71 \\
\hline Gdańsk & 470,907 & 2.4 & 7738.94 & 93.88 \\
\hline Gorzów Wielkopolski & 123,609 & 2.3 & 6567.33 & 59.59 \\
\hline Katowice & 292,774 & 1.0 & 7437.27 & 72.53 \\
\hline Kielce & 194,852 & 4.9 & 636.28 & 71.41 \\
\hline Kraków & 779,115 & 2.0 & 630.02 & 95.88 \\
\hline Lublin & 339,774 & 5.0 & 6941.85 & 81.04 \\
\hline Łódź & 679,941 & 4.8 & 6600.84 & 62.87 \\
\hline Olsztyn & 171,979 & 2.7 & 7597.00 & 81.84 \\
\hline Opole & 128,035 & 2.8 & 8902.51 & 91.23 \\
\hline Poznań & 534,813 & 1.1 & 7766.51 & 94.52 \\
\hline Rzeszów & 196,208 & 4.8 & 7533.14 & 94.46 \\
\hline Szczecin & 401,907 & 2.4 & 6563.20 & 97.60 \\
\hline Toruń & 201,447 & 4.1 & 6385.79 & 74.58 \\
\hline Warszawa (capital) & $1,790,658$ & 1.3 & 10154.88 & 98.96 \\
\hline Wrocław & 642,869 & 1.6 & 7681.46 & 91.80 \\
\hline Zielona Góra & 141,222 & 2.4 & 7644.04 & 52.09 \\
\hline
\end{tabular}

Civic budget reports are published on Public Information Bulletin websites. The CB process has the following key milestones:

- A deadline for submitting proposals is set,

- A coordination and evaluation team is appointed,

- The submitted proposals undergo formal and content-related verification,

- Appeals are processed,

- The list of projects approved for voting is published,

- Votes are cast and the results are published,

- The selected projects are implemented.

Civic budget reports vary significantly in content because there are no standardized reporting guidelines. In most cases, the reports include budget estimates for the implementation of the proposals, and projects are divided into district or city-wide measures. The reports list the number of the submitted projects and the number of voters. Some reports contain information about the number of eligible voters, voter turnout, estimated project costs, and the progress made in each project.

Civic budgeting reports were analyzed to determine the number of votes cast in each city and in all evaluated cities, and projects addressing public spaces were divided into categories. The number of projects in each category and the funds allocated for their implementation were analyzed.

A minimum sample size was determined for each city to determine whether the voters formed a representative sample of the entire community. The minimum sample size was calculated with the use of the below formula (1): 


$$
N_{\min }=\frac{P(1-P)}{\frac{e^{2}}{z^{2}}+\frac{P(1-P)}{N}}
$$

where:Nmin - minimum sample size, $\mathrm{P}$ — estimated fraction size (default value of 50\%), $\mathrm{z}$ statistical significance $(\alpha)$ calculated using the cumulative distribution function of the normal distribution (95\%), $\mathrm{N}$ - size of the general population for a finite population (number of inhabitants),e-maximum error of the estimate (0.01).

In the last step, the analyzed cities were ranked in terms of civic attitudes, civic participation and social engagement. The results were compared with voter turnout in CB. Civicoriented cities were ranked based on a synthetic index composed of standardized measures of civic attitudes, including:

$\mathrm{X}_{1}$ - voter turnout in elections to the Sejm and Senate in 2019,

$\mathrm{X}_{2}$ - number of candidates in local elections in 2018,

$\mathrm{X}_{3}$-number of NGOs per 10,000 inhabitants,

$\mathrm{X}_{4}$-number of public benefit organizations per 10,000 inhabitants,

$\mathrm{X}_{5}$ - voter turnout in CB in 2019,

$\mathrm{X}_{6}$-number of public consultations in 2019,

$\mathrm{X}_{7}$-number of registered public gatherings in 2019,

$\mathrm{X}_{8}$-number of submitted public information requests per 10,000 inhabitants in 2019.

Absolute variables were standardized with the use of formula (2) to produce dimensionless variables and to calculate the ranking value:

$$
R=\sum_{k=1}^{n} \frac{x-\mu}{\delta}
$$

where: $\mathrm{R}$ — city's rank, $\mathrm{n}$-number of variables, $\mathrm{x}$-non-standardized variable, $\mu$-population mean, $\delta$ - standard deviation of the population.

The analyzed data were obtained from the reports of the National Electoral Commission, the National Court Register, the list of non-governmental organizations kept by the Klon-Jawor Association, from Budget reports, Public Information Bulletin websites, and the reports published by the evaluated cities.

\section{Results and Discussion}

\subsection{Civic Budget Vote}

The number of voters exceeded the minimum sample size in each of the surveyed cities. Therefore, it can be assumed that the votes cast in the Civic Budget were representative of each city. In Gorzów Wielkopolski, the city with the smallest population, the required sample size was 8912 . Votes were cast by 14,327 inhabitants; therefore, the minimum sample size was met. The number of voters was highest in Łódź (around 167,000) and lowest in Torun (around 11,000). Voter turnout and the total population of the capital city in each voivodeship are presented in Fig. 2.

The percentage voter turnout relative to total population is shown in Fig. 3. Voter turnout was highest in Rzeszów at around $40 \%$ and lowest in Warsaw (the Polish capital) and Toruń at $6 \%$ each. 


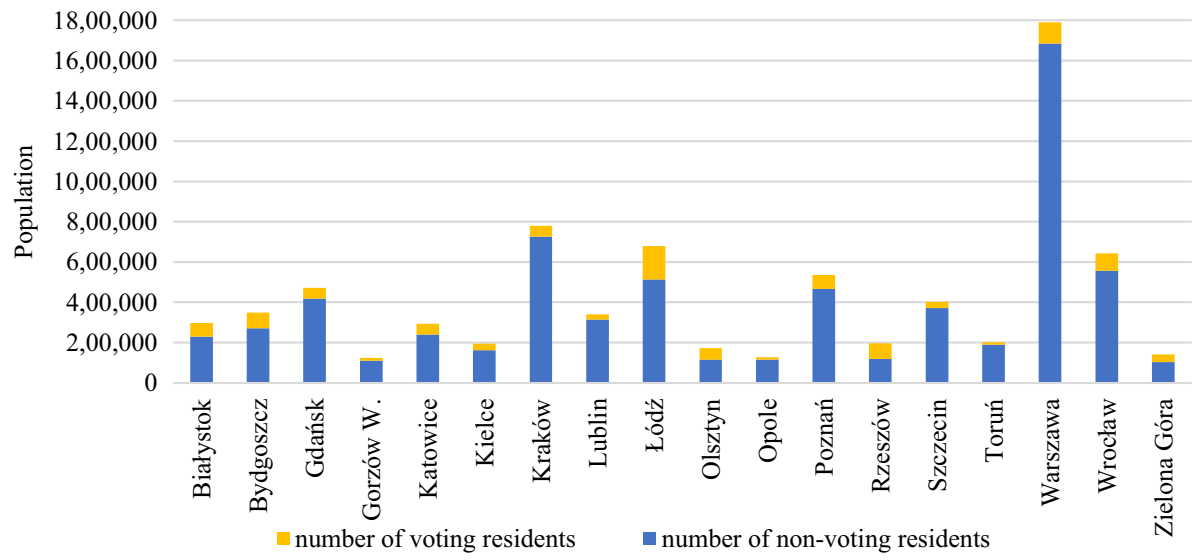

Fig. 2 Population and voter turnout in the capital cities of Polish voivodeships. Source: own study

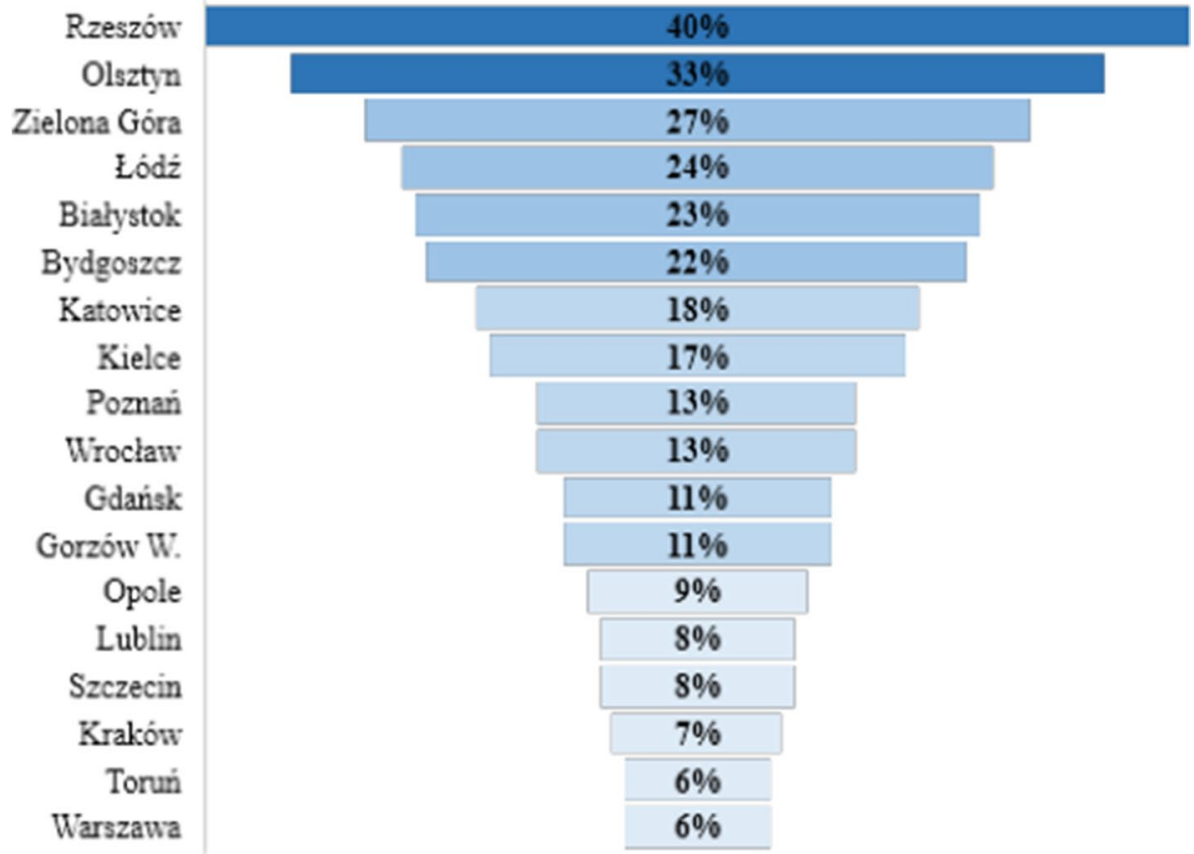

Fig. 3 CB voter turnout in the capital cities of Polish voivodeships. Source: own study

The number of votes cast online and in polling stations is presented in Fig. 4. Votes could only be cast online in Gdańsk, Katowice, Opole and Poznań. In the remaining cities where residents could vote online or in polling stations, the vast majority of votes were cast online. The only exceptions were Białystok and Gorzów Wielkopolski, where voting at the ballot box was more popular. According to Brzeziński (2017), the availability of both conventional and online voting options can increase turnout among younger as well as 


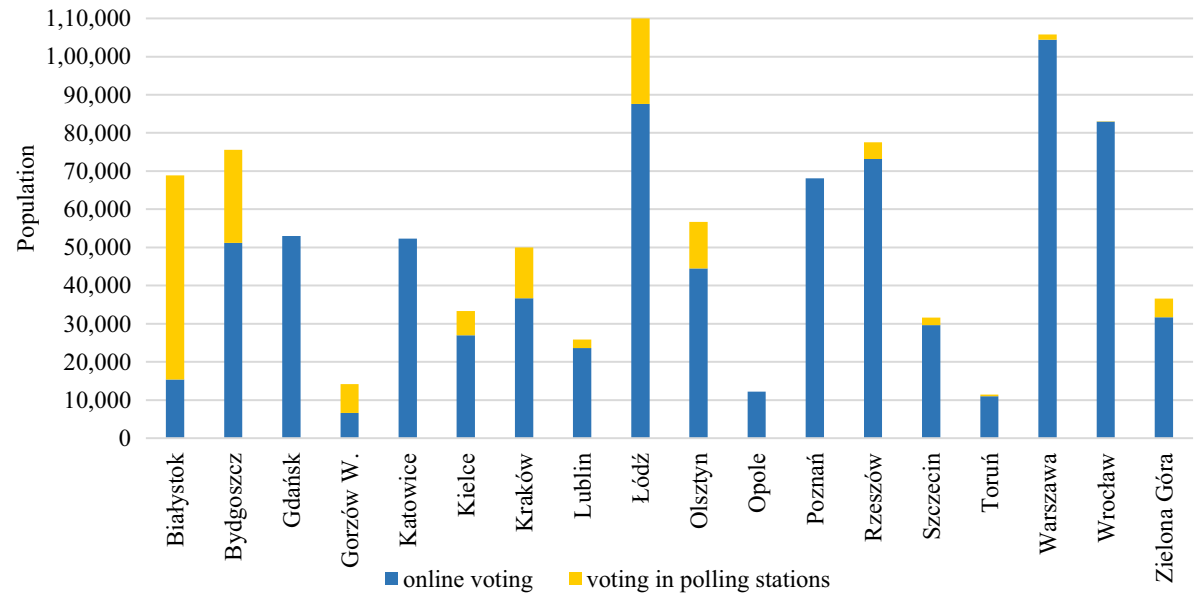

Fig. 4 Form of CB voting in the capital cities of Polish voivodeships. Source: own study

Table 2 Proportions of civic budgets in the expenditures of the capital cities of Polish voivodeships. Source: own study

\begin{tabular}{lll}
\hline City & $\begin{array}{l}\text { CB as \% of } 2018 \text { budgeted } \\
\text { expenditure-min value } \\
0.005\end{array}$ & $\begin{array}{l}\text { Difference between } \\
\text { minimum and actual } \\
\text { value }\end{array}$ \\
\hline Białystok & 0.006 & $0.001 \uparrow$ \\
Bydgoszcz & 0.008 & $0.003 \uparrow$ \\
Gdańsk & 0.006 & $0.001 \uparrow$ \\
Gorzów W & 0.008 & $0.003 \uparrow$ \\
Katowice & 0.013 & $0.008 \uparrow \uparrow$ \\
Kielce & 0.006 & $0.001 \uparrow$ \\
Kraków & 0.005 & $0.000=$ \\
Lublin & 0.006 & $0.001 \uparrow$ \\
Łódź & 0.012 & $0.007 \uparrow \uparrow$ \\
Olsztyn & 0.005 & $0.000=$ \\
Opole & 0.005 & $0.000=$ \\
Poznań & 0.006 & $0.001 \uparrow$ \\
Rzeszów & 0.007 & $0.002 \uparrow$ \\
Szczecin & 0.005 & $0.000=$ \\
Toruń & 0.006 & $0.001 \uparrow$ \\
Warszawa & 0.005 & $0.000=$ \\
Wrocław & 0.005 & $0.000=$ \\
Zielona Góra & 0.006 & $0.001 \uparrow$ \\
\hline & &
\end{tabular}

$\uparrow:$ small difference (actual value is greater than minimum value), $\uparrow \uparrow:$ large difference (actual value is much greater than minimum value), = no difference (actual value is the same as minimum value)

older voters, and the example of Białystok and Gorzów Wielkopolski seems to confirm this observation.

The cost of CB was evaluated in the next step of the analysis. In Poland, the value of the civic budget is minimum $0.5 \%$ of the city's expenditures in the previous year. The 


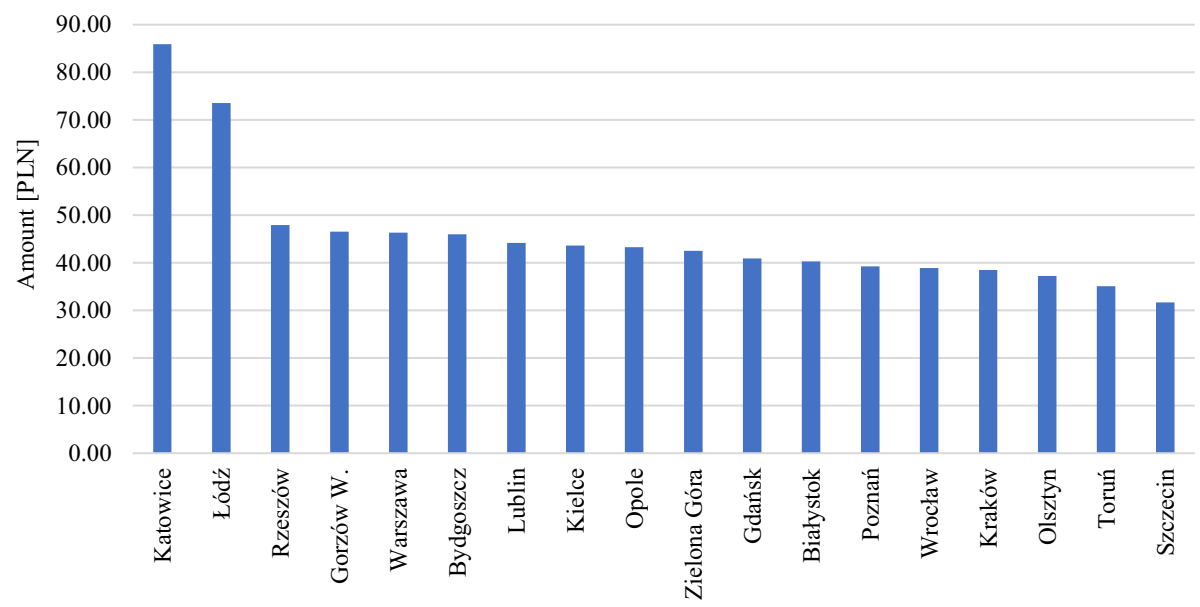

Fig. 5 Average value of civic budgets per capita in the capital cities of Polish voivodeships. Source: own study

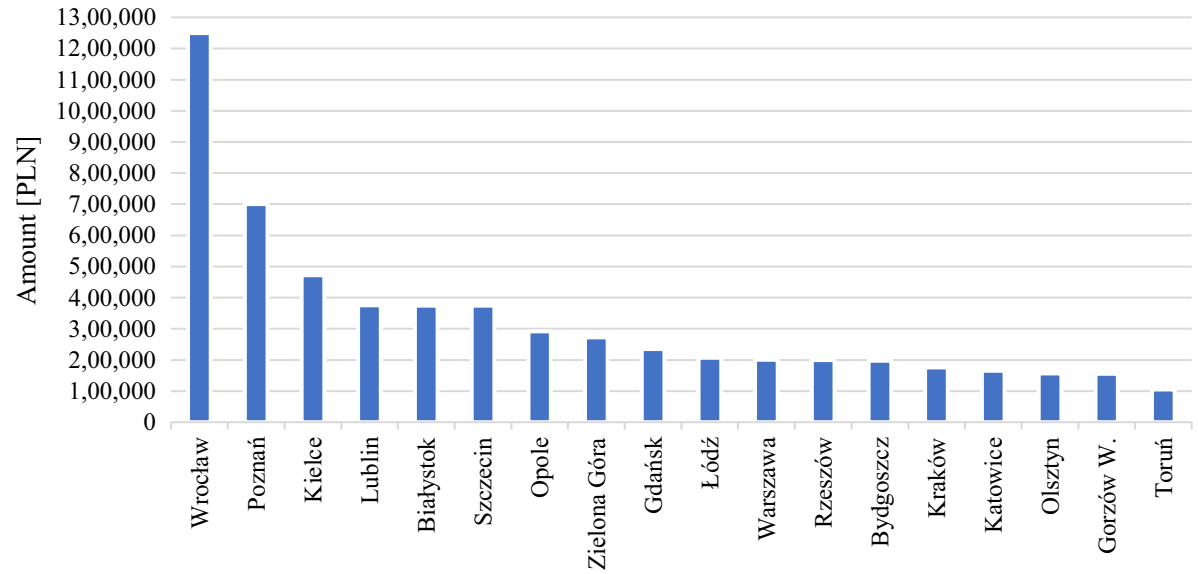

Fig. 6 Average value of a CB project in the capital cities of Polish voivodeships. Source: own study

proportions of civic budgets in the expenditures of the 18 analyzed cities are presented in Table 2. In six cities, CB budgets did not exceed the minimum statutory threshold. The allocated funds were higher in the remaining cities. Civic budgets were highest in Katowice and Łódź, where they accounted for $0.8 \%$ and $0.7 \%$ of the cities' expenditures, respectively. Research studies conducted in other large Polish cities have also confirmed that civic budgets account for a miniscule proportion of urban expenditures (Szaranowicz-Kusz, 2016). According to Błaszak (2019), civic budgets do not play a significant role in fiscal planning; therefore, the effectiveness of civic budgets does not influence the effectiveness of city budgets.

The value of CB per capita ranged from PLN 31 in Szczecin to PLN 86 in Katowice (Fig. 5). The remaining cities had similar civic budgets, excluding Katowice and Łódź where the spending on $\mathrm{CB}$ was considerably higher and exceeded twice the minimum statutory threshold. 
Average project value was highest in Wrocław, and it was more than several times higher than in the majority of the remaining cities. The lowest value per project was recorded in Torun (Fig. 6). These differences result from the number of submitted projects. The higher the number and fragmentation of the submitted projects and the smaller the funds earmarked for $\mathrm{CB}$, the lower the average value of a project.

\subsection{Public Spaces in Civic Budgeting}

The analysis covered several categories of CB projects. The projects relating to public spaces were divided into 8 categories:

- urban greens, including municipal parks, green squares, urban green landscapes,

- sports/recreation, including sports fields and facilities, outdoor gyms and various forms of sporting activities,

- playgrounds, including playground development and expansion,

- revitalization, including general renewal of public spaces in whole or in part,

- transport, including urban infrastructure such as roads, streets, bicycle paths and parking lots, pavement construction or replacement, bus stops,

- lighting, including in sports fields, streets and pavements,

- surveillance, including audio-visual security systems,

- land management, including the development of public spaces, installing or upgrading public facilities in a manner consistent with their intended use or expectations.

The distribution of total votes (in all analyzed cities) in each project category is presented in Fig. 7. "Land management" and "Transport" attracted nearly 50\% of the votes and were regarded as categories where greatest improvement was needed. They were followed by "Urban greens", "Animal care", and "Culture and entertainment" categories. These results indicate that the quality of public spaces and public transport in cities was prioritized by the residents. Public spaces are frequently visited and used by members of the local community, whereas public transport is essential to living in a city. "Surveillance", "Revitalization" and "Lighting" received only $2 \%$ of the votes, which suggests that technical concerns and the renewal of the existing public spaces are not primary concerns.

Fig. 7 Structure of civic budgets in terms of the number of votes cast in different categories of projects in the capital cities of Polish voivodeships. Source: own study

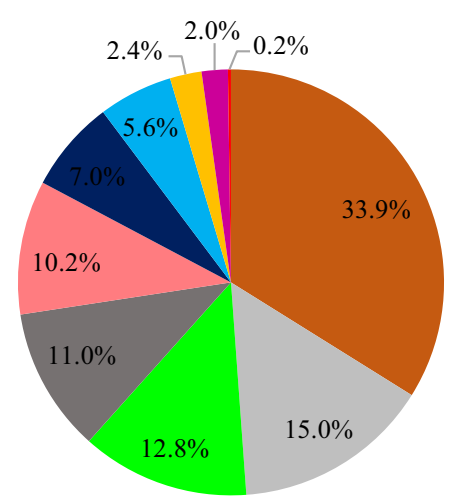

- land management/public facilities

transport

urban greens

animal care

- culture/entertainment

- sports/recreation

- playgrounds 


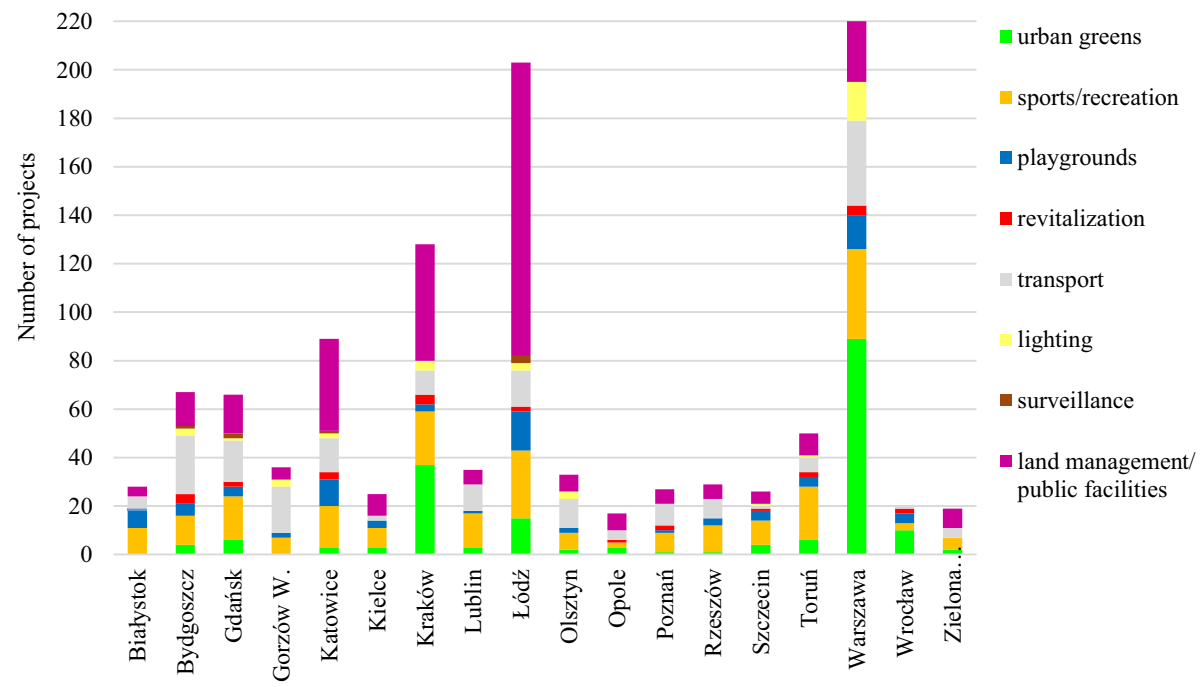

Fig. 8 Number of CB projects in categories related to public spaces in the capital cities of Polish voivodeships. Source: own study

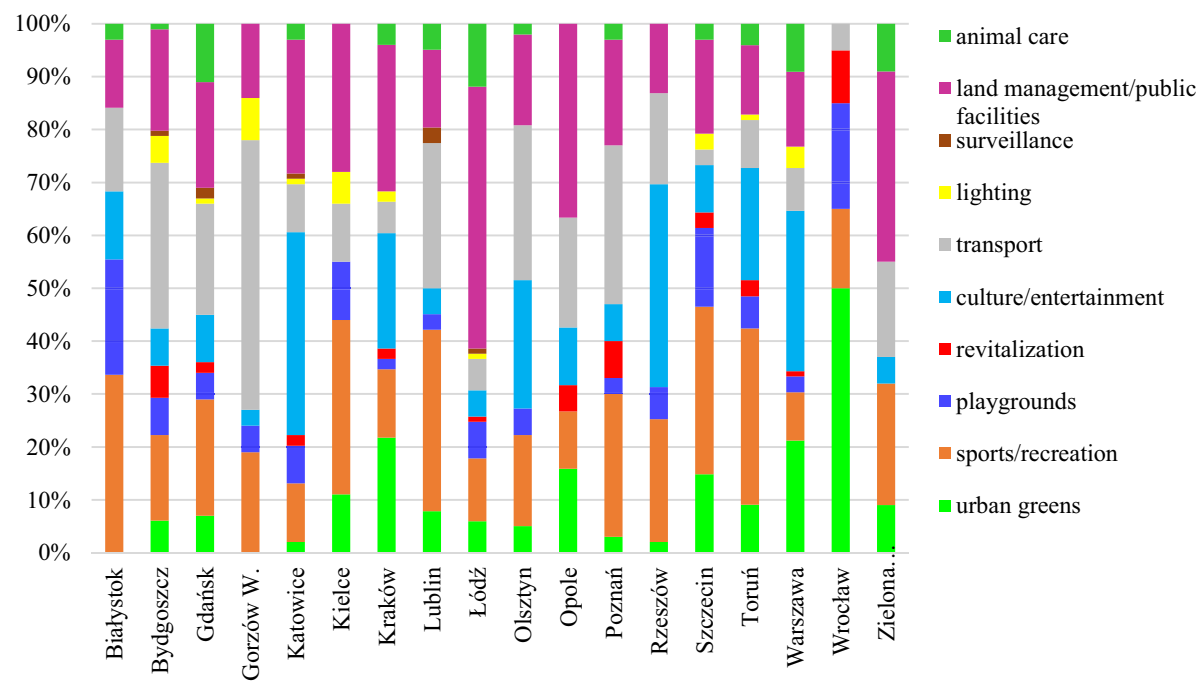

Fig. 9 Proportions of different categories of CB projects in the capital cities of Polish voivodeships. Source: own study

An analysis of the programs implemented in other large cities indicates that the adopted categories are most popular among local residents, which confirms that these issues make the greatest contribution to the functioning and attractiveness of public spaces (Rybińska, 2018).

The proportions of different project categories in percentage terms and in absolute values are presented in Figs. 8 and 9. "Land management" received the highest overall score, and it was most popular in Łódź, Opole and Zielona Góra, where it attracted 50\%, 37\% and 
$36 \%$ of total votes and scored well above the average. Land management projects were not submitted in Wrocław, and this category received the lowest support (13\%) in Białystok, Rzeszów and Torun. The second most popular category was "Transport" which enjoyed the greatest support in Gorzów Wielkopolski (51\%), Bydgoszcz (31\%) and Poznań (30\%), and the smallest support in Szczecin (3\%) and Wrocław (5\%). "Urban greens", a key element of public spaces, was the most popular category in Wrocław (50\%), Kraków (21\%) and Warsaw (20\%). It received minimal support in Katowice, Rzeszów and Poznań (2-3\%), and did not elicit any interest from the residents of Białystok and Gorzów Wielkopolski. "Surveillance" was the least popular category that was not proposed in most of the evaluated cities and accounted for only $3 \%$ of the projects implemented in Lublin, $2 \%$ in Gdańsk and 1\% in three other cities. "Revitalization" was the second least popular category with marginal support in several cities, excluding Wrocław, where it accounted for $10 \%$ of the projects slated for implementation. "Lighting" was the third least popular category, and the relevant proposals were submitted in approximately half of the surveyed cities, but did not exceed $8 \%$ of the votes in any city. These findings suggest that the most popular project categories target local communities' vital needs. According to Sorychta-Wojsczyk (2015), the Porto Alegre model focuses on specific investment projects, and it enables the residents to exercise real power (the local authorities are open to the citizens' suggestions and modify the proposed solutions accordingly).

The overall structure of $\mathrm{CB}$ projects in terms of the number of projects submitted in the analyzed categories is presented in Fig. 10. In all examined cities, the largest number of projects were submitted in "Land management" and "Culture / entertainment" categories, followed by "Sports / recreation" and "Transport". Similarly to the previous analysis, "Surveillance", "Revitalization" and "Lighting" were the least popular categories.

The structure of expenses by project category is shown in Fig. 11. In most cities, most funds were allocated to projects relating to land management, sports/recreation and transport. Considerable funds were allocated to urban greenery projects in Kraków, Wrocław and Łódź.

Similar trends were observed in an analysis of total expenditure. The highest proportion of expenses was noted in the "Land management" (approx. 25\%), "Transport" and "Urban greenery" (approx. 20\% each) categories. "Surveillance", "Animal care" and "Culture/ entertainment" projects had the smallest share of total spending (2-3\%) (Fig. 12).

The results of the above analyses indicate that land management in the existing public spaces and the provision of new public facilities are of paramount public interest. This

Fig. 10 Structure of CB projects by category in the capital cities of Polish voivodeships. Source: own study

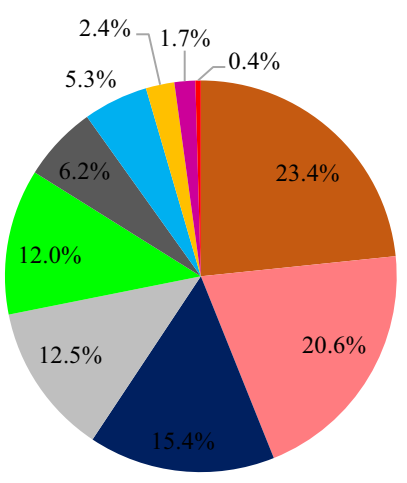




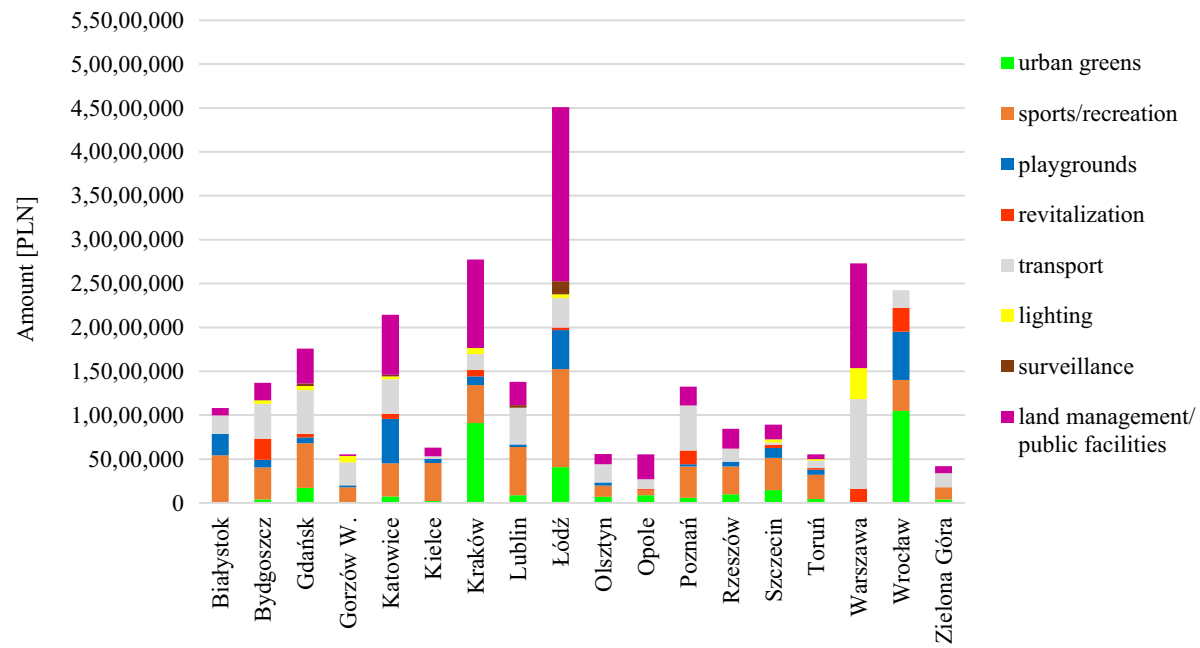

Fig. 11 Structure of expenses in CB project categories related to public spaces in the capital cities of Polish voivodeships. Source: own study
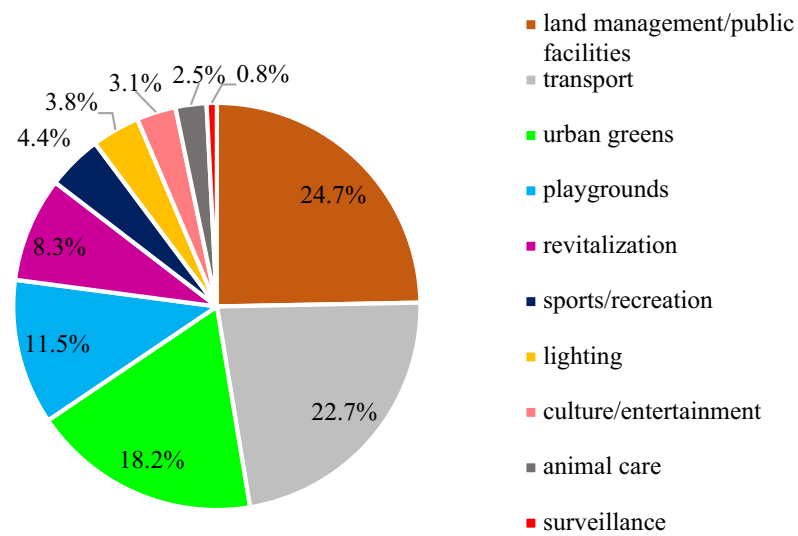

Fig. 12 Structure of CB projects by the costs incurred in the capital cities of Polish voivodeships. Source: own study

category of projects received the highest score in terms of the number of voters, number of projects in each category, percentage share of each category, and structure of projects and expenses. "Transport", "Urban greens" and "Sports/recreation" also received very high support in all cities. The submitted projects were least likely to address "Surveillance", "Lighting" and "Revitalization" categories. In some cities (Kielce, Olsztyn, Rzeszów, Zielona Góra), projects in the above categories were not implemented. Similar observations were made in other studies which demonstrated that most $\mathrm{CB}$ projects focus on "hard" infrastructure (Chruściński et al., 2014; Kalisiak-Mędelska, 2016; Sołecka \& Dworniczak, 2016; Mucha, 2018; Węglarz, 2018). Social and technical infrastructure (including sports and recreation) are the leading themes in the submitted projects (Mucha, 2018). 


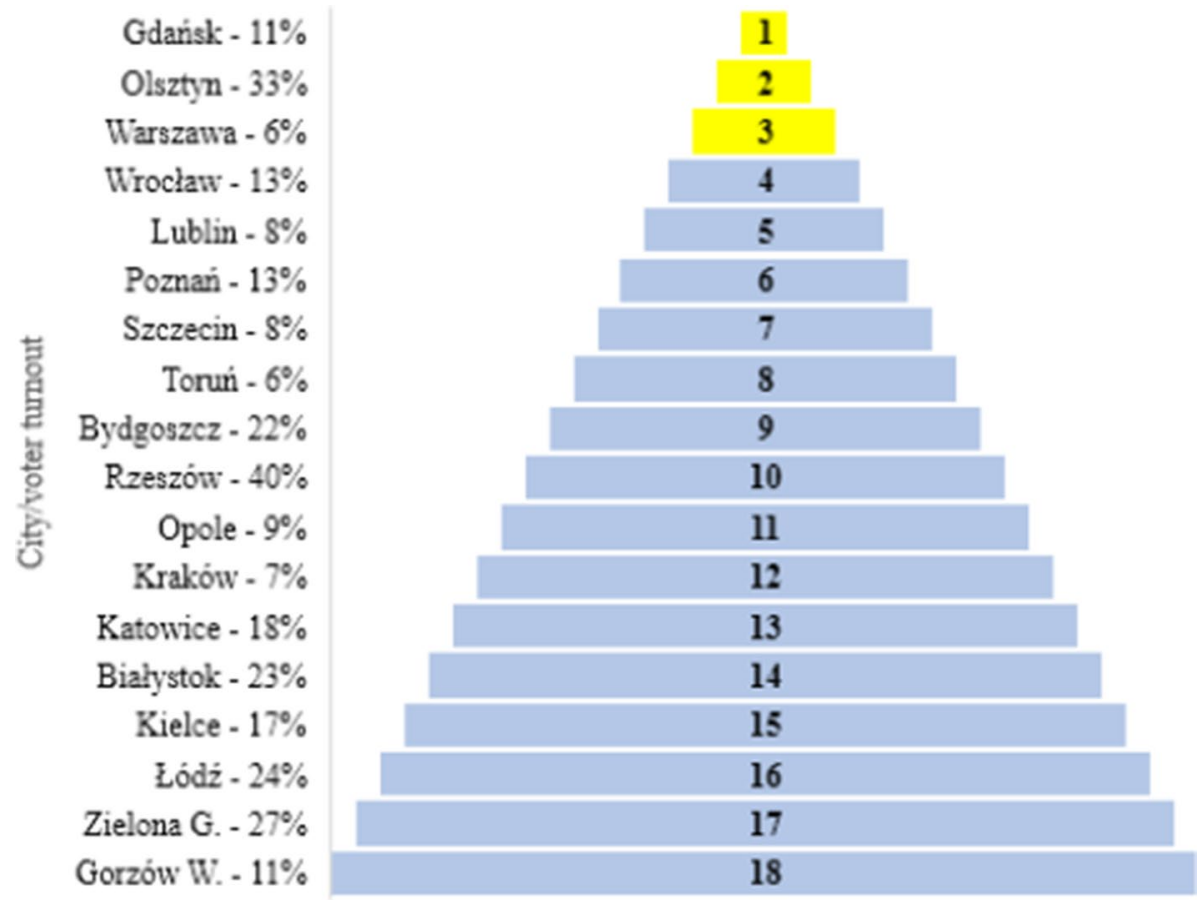

Fig. 13 Ranking of civic-oriented cities. Source: own study

\subsection{Ranking of Civic-oriented Cities}

The analyzed cities were ranked based on the local communities' civic engagement. The results of the ranking and voter turnout in $\mathrm{CB}$ in each city are presented in Fig. 13. An analysis of these findings indicates that civic engagement is not always correlated with high voter turnout in CB. The highest correlation was noted in Olsztyn which ranked second and where high levels of civic activity were reported. In turn, Warsaw ranked third, but community participation in CB was low. Relatively high similarities were also observed in Bydgoszcz and Opole. Together with Warsaw, Lublin, Toruń and Gdańsk belong to a group of cities characterized by a high score in the civic-oriented ranking, but low voter turnout in CB. Zielona Góra, Łódź, Rzeszów and Białystok belong to a separate group of cities that received a low score in the ranking despite the fact that local community members actively participate in $\mathrm{CB}$. These observations suggest that voter turnout in $\mathrm{CB}$ is not the key determinant of a city's position in the ranking.

The correlations between voter turnout in $\mathrm{CB}$ and per capita income in the analyzed cities in 2019 were also examined. The correlation coefficient was close to zero, which indicates that average economic growth expressed by local government revenue per capita does not influence civic engagement. 


\section{Summary and Conclusions}

Civic budgeting is a form of public consultation that aims to engage community members in decision-making in matters that affect the quality of local life. It is undertaken to collect information on diverse social needs, activate local communities, increase their involvement in projects that benefit their city, and to build social trust. Therefore, the higher the voter turnout, the greater the community's involvement in local affairs, which increases the likelihood that the implemented projects will better meet the local residents' needs and expectations. More than one million citizens, i.e. around 13\% of the combined population of Poland's largest cities, voted on civic budgets in the capital cities of Polish voivodeships. This percentage can be regarded as a representative sample because the number of voters in each city exceeded the minimum sample size.

Many of the examined cities received vastly different scores in the ranking of civicoriented cities and the ranking of CB voters in 2019. These differences can be attributed to numerous factors, including the diversity of Polish society, the effectiveness of marketing activities undertaken by city councils to promote participation in $\mathrm{CB}$, local governments' willingness to establish a dialogue with the residents and create a platform for stakeholder cooperation, selfless activism and mutual trust. An analysis of local governments' efforts to promote the $\mathrm{CB}$ concept validates these observations. It should be emphasized that citizenship is influenced by numerous factors that have shaped the development of cities and are rooted in their history. In Polish cities, civic attitudes remain an element of a culture that had evolved during partitions, wars, resettlements, social and economic policies of the communist authorities, and democratic elections of deputies and mayors. Therefore, attitudes towards civic engagement are closely linked with the history of urban development and society in the past two centuries (Borowiec, 2006; Pietrzak et al., 2010; Wendt, 2007).

Most of the local needs that were identified based on the number of votes cast for different categories of $\mathrm{CB}$ projects were related to public spaces, including land management and the provision of public facilities, both in individual cities and nationwide. The above can be largely attributed to the role public spaces play in local communities, including their contribution to social integration, recreation, relaxation and physical activity. These are primary needs, which is why they were so strongly emphasized in CB. Public areas are generally located in the immediate vicinity of one's place of residence and they directly influence the quality of local life. Infrastructure and transport solutions that improve public mobility were also recognized as highly important.

Participation in the CB process, both at the stage of project submission and voting, provides citizens with certain control over the management of public funds. By actively participating in the process, local communities develop civic attitudes, their members become active and accept their share of responsibility and influence over the development of urban habitat. Residents who assume joint responsibility for their place of residence decide on the organization and functionality of their living environment. This observation was corroborated by the results of civic budgets evaluations in the examined cities, where the most commonly cited reasons for voting were:

- the subject matter and scope of the projects addressed the immediate needs of the residents,

- the project was connected to one's place of residence or its immediate neighborhood,

- the project created new leisure opportunities,

- the project improved accessibility to urban spaces, 
- the project met local community's aspirations, enabled personal development or the pursuit of hobbies.

The analysis of the results of $\mathrm{CB}$ evaluations also revealed that $\mathrm{CB}$ projects are most often proposed by professionally active people aged 30-50 years. Therefore, the postulated problems and issues could largely reflect the needs of this social group, whereas young people and seniors could be underrepresented. Youths and seniors are least likely to submit $\mathrm{CB}$ proposals because the procedure requires at least basic knowledge of economics and law. The submitted projects must be well described and justified; they have to be consistent with formal requirements, local plans, programs and strategies. Every proposal must also include a cost estimate. These factors can prevent certain stakeholder groups from participating in the $\mathrm{CB}$ process.

The analysis of the $\mathrm{CB}$ process also revealed that the adopted rules and procedures differed across the examined cities. In the authors' opinion, the CB process should be based on identical principles and requirements, including voting age (without restrictions and, in some cases, over 16), collection of signatures in petitions supporting a given project, estimated budget for the implementation of specific project tasks with a division into city and district projects, the number of submitted projects, the number of voters, and a report on the progress made in a given project.

Community participation in the preparation of $\mathrm{CB}$ projects and voting is a good example of civic engagement. Residents who join such projects express their willingness to participate in the life of the city, make joint decisions and co-manage urban space. Participants value the opportunity to make decisions on issues that are important to the local community, and to improve the quality of life in their neighborhoods. Participation in CB activates the local community and increases its engagement. It fosters a better understanding of local governments' duties and obligations, and the mechanisms of local governance. In this regard, the concept of citizenship is not confined to social attitudes, but it also includes the policies and measures undertaken by the local government, including its willingness to enter into dialogue with the residents.

The results of the present study make a valuable contribution to international literature on civic engagement and voter turnout in $\mathrm{CB}$ in urban communities. The study identified the most pressing needs of urban residents, and it demonstrated that local communities' needs and expectations are not influenced by a city's size or rank, population structure, level of development, geographic location or history. The study revealed that city dwellers have similar priorities and expectations concerning public spaces.

In the future, a similar study could be conducted in smaller cities and towns to determine whether the local residents' needs and expectations concerning public spaces are similar to those noted in large urban agglomerations. In the authors' opinion, this line of inquiry is an interesting topic for future research.

Open Access This article is licensed under a Creative Commons Attribution 4.0 International License, which permits use, sharing, adaptation, distribution and reproduction in any medium or format, as long as you give appropriate credit to the original author(s) and the source, provide a link to the Creative Commons licence, and indicate if changes were made. The images or other third party material in this article are included in the article's Creative Commons licence, unless indicated otherwise in a credit line to the material. If material is not included in the article's Creative Commons licence and your intended use is not permitted by statutory regulation or exceeds the permitted use, you will need to obtain permission directly from the copyright holder. To view a copy of this licence, visit http://creativecommons.org/licenses/by/4.0/. 


\section{References}

Aleksandrov, E., Bourmistrov, A., \& Grossi, G. (2018). Participatory budgeting as a form of dialogic accounting in Russia: Actors' institutional work and reflexivity trap. Accounting, Auditing \& Accountability Journal, 31(4), 1098-1123. https://doi.org/10.1108/AAAJ-02-2016-2435

Augsberger, A., Collins, M. E., Gecker, W., Lusk, K., \& Zhao, Q. J. (2017). She treated us like we bring valid ideas to the table: Youth experiences of a youth-led participatory budgeting process. Children and Youth Services Review, 76(C), 243-249. https://doi.org/10.1016/j.childyouth.2017.02.025

Baiocchi, G. G., \& Ganuza, E. (2014). Participatory budgeting as if emancipation mattered. Politics \& Society, 42(1), 1-20. https://doi.org/10.1177/0032329213512978

Barnes, M., Newman, J., Knops, A., \& Sullivan, H. (2003). Constituting 'the public'in public participation. Public Administration, 81(2), 379-399.

Bartocci, L., Grossi, G., \& Mauro, S. G. (2019). Towards a hybrid logic of participatory budgeting. International Journal of Public Sector Management, 32(1), 65-79. https://doi.org/10.1108/ IJPSM-06-2017-0169

Basaj, M. (2013). Instrumenty partycypacji społecznej w teorii i praktyce zintegrowanego zarządzania miastem. Acta Universitatis Nicolai Copernici. Zarzadzanie, 40, 279-288.

Benita, F., Bansal, G., \& Tunçer, B. (2019). Public spaces and happiness: Evidence from a large-scale field experiment. Health \& Place, 56, 9-18. https://doi.org/10.1016/j.healthplace.2019.01.014

Bherer, L., Fernández-Martínez, J. L., Espín, P. G., \& Sánchez, M. J. (2016). The promise for democratic deepening: The effects of participatory processes in the interaction between civil society and local governments. Journal of Civil Society, 12(3), 344-363. https://doi.org/10.1080/17448689. 2016.1215957

Błaszak, M. (2019). Budżet obywatelski w Polsce i dylematy z nim związane. Ruch Prawniczy, Ekonomiczny i Socjologiczny, 81(3), 203-220.

Borowiec, P. (2006). Główne przeszkody w realizacji idei społeczeństwa obywatelskiego. Główne przeszkody w realizacji idei społeczeństwa obywatelskiego. In B. Krauz-Mozer \& P. Borowiec (Eds.), Czas społeczeństwa obywatelskiego (pp. 143-158). Wydawnictwo Uniwersytetu Jagiellońskiego.

Boryczka, E. M. (2015). Partycypacyjne instrumenty zarządzania jednostkami samorządu terytorialnego. In A. Nowakowska (Ed.), Nowoczesne metody i narzedzia zarzadzania rozwojem lokalnym $i$ regionalnym (pp. 39-86). Wydawnictwo Uniwersytetu Łódzkiego.

Brzeziński, K. (2017). Budżet (nie) obywatelski?-analiza czterech edycji łódzkiego budżetu obywatelskiego. Pedagogika Społeczna, 3, 135-155.

Cabannes, Y. (2004). Participatory budgeting: A significant contribution to participatory democracy. Environment and Urbanization, 16(1), 27-46. https://doi.org/10.1177/095624780401600104

Chruściński, J., Palińska, I., \& Kazak, J. (2014). Participatory budgeting in the management of public space. Architektura Krajobrazu, 3(2014), 56-67.

Coarelli, F. (1982). Rzym. Morze Śródziemne. Gdańsk: Wyd. Morskie.

Dymnicka, M. (2013). Przestrzeń publiczna a przemiany miasta. Warszawa: Wyd. Naukowe Scholar, pp. 53.

Džinić, J., Svidroňová, M. M., \& Markowska-Bzducha, E. (2016). Participatory budgeting: A comparative study of Croatia, Poland and Slovakia. Nispacee Journal of Public Administration and Policy, 9(1), 31-56. https://doi.org/10.1515/nispa-2016-0002

Falanga, R., \& Lüchmann, L. H. H. (2020). Participatory budgets in Brazil and Portugal: Comparing patterns of dissemination. Policy Studies, 41(6), 603-622. https://doi.org/10.1080/01442872.2019. 1577373

Ganuza, E., Nez, H., \& Morales, E. (2014). The struggle for a voice: Tensions between associations and citizens in participatory budgeting. International Journal of Urban and Regional Research, 38(5), 2274-2291. https://doi.org/10.1111/1468-2427.12059

Garbacz, E., Komornicki, T., \& Kowalczyk, K. (2020). Dostępność dzienna w układzie miast wojewódzkich w Polsce. Przeglad Geograficzny, 92(2), 247-265. https://doi.org/10.7163/PrzG.2020.2.5

Gawroński, H. (2015). Efektywność partycypacyjnych instrumentów zarządzania miastem. Ruch Prawniczy, Ekonomiczny i Socjologiczny, 77(1), 273-286. Doi: https://doi.org/10.14746/rpeis.2015.77.1.15

Gehl, J. (2011). Life between buildings: Using public space. Island Press.

Goldfrank, B. (2007). Lessons from latin American experience in participatory budgeting participatory budgeting. In A. Shah (Ed.), Participatory budgeting public sector governance and accountability (pp. 91-121). Washington, DC: World Bank.

Gómez, J., Insua, D. R., \& Alfaro, C. (2016). A participatory budget model under uncertainty. European Journal of Operational Research, 249(1), 351-358. https://doi.org/10.1016/j.ejor.2015.09.024 
Janiszek, M., \& Majorek, A. (2017). Waloryzacja przestrzeni miejskiej na podstawie projektów zrealizowanych w ramach budżetu obywatelskiego. Biuletyn KPZK, 268, 167-185.

Jurkowski, W. (2018). Integracja głównych dworców autobusowych i kolejowych w miastach wojewódzkich w Polsce. Przeglad Komunikacyjny, 73(5), 22-26.

Kalisiak-Mędelska, M. (2016). Budżet obywatelski w Polsce. Analiza porównawcza Łodzi i Poznania. Prace Naukowe Uniwersytetu Ekonomicznego We Wrocławiu, 443, 103-114. https://doi.org/10. 15611/pn.2016.443.10

Kamrowska-Zaluska, D. (2016). Participatory budgeting in Poland-missing link in urban regeneration process. Procedia Engineering, 161, 1996-2000. https://doi.org/10.1016/j.proeng.2016.08.792

Kębłowski, W. (2014). Budżet partycypacyjny. Ewaluacja. Instytut Obywatelski, Warszawa, doi: https:// doi.org/10.13140/2.1.3106.1123.

Kersting, N., Gasparikova, J., Iglesias, A., \& Krenjova, J. (2016). Local democratic renewal by deliberative participatory instruments: participatory budgeting in comparative study. In S. Kuhlmann \& G. Bouckaert (Eds.), Local public sector reforms in times of crisis governance and public management. Palgrave Macmillan. https://doi.org/10.1057/978-1-137-52548-2_18

Komorowski, J. W. (2012). Miasta wojewódzkie a miasta postwojewódzkie w Polsce-zróżnicowanie i zmiany poziomu gospodarczego w pierwszej dekadzie XXI wieku. Studia Miejskie, 8, 9-25.

Koohsari, M. J., Mavoa, S., Villanueva, K., Sugiyama, T., Badland, H., Kaczynski, A. T., Oven, N., \& Giles-Corti, B. (2015). Public open space, physical activity, urban design and public health: Concepts, methods and research agenda. Health \& Place, 33, 75-82. https://doi.org/10.1016/j.healt hplace.2015.02.009

Kraszewski, D., \& Mojkowski, K. (2014). Budżet obywatelski w Polsce. Fundacja im. Stefana Batorego, Warszawa.

Lin, M., \& Chen, K. (2020). Participation effectiveness of citizen participatory budgeting: The case of Yanjin County in China. Chinese Public Administration Review, 11(1), 6-24. https://doi.org/10. 22140/cpar.v11i1.247

Local Data Bank. (2018). https://bdl.stat.gov.pl/BDL/start. Accessed 20 Jan 2021.

Lorens, P., \& Martyniuk-Pęczek, J. (2010). Problemy kształtowania przestrzeni miejskich. Urbanista, Gdańsk, p. 21.

Lynch K., 2011. Obraz miasta. Wyd. Archivolta, Kraków.

Madanipour, A. (1999). Why are the design and development of public spaces significant for cities? Environment and Planning b: Planning and Design, 26(6), 879-891. https://doi.org/10.1068/b2608 79

Mannarini, T., \& Fedi, A. (2018). Using quali-quantitative indicators for assessing the quality of citizen participation: A study on three citizen juries. Social Indicators Research, 139, 473-490. https://doi. org/10.1007/s 11205-017-1735-9

Martela, B. (2013). Budżet partycypacyjny w Polsce-wdrożenie i perspektywy. Władza sqdzenia, 2, 22-33.

Mews, G. H., Muminovic, M., \& Tranter, P. (2018). Time for action. Implementing the New Urban Agenda in public spaces for health and wellbeing. The Journal of Public Space, 3(1), 193-202. https://doi.org/10.5204/jps.v3i1.330

Mohammadi, S. H., Norazizan, S., \& Nikkhah, H. A. (2018). Conflicting perceptions on participation between citizens and members of local government. Quality \& Quantity, 52, 1761-1778. https:// doi.org/10.1007/s11135-017-0565-9

Mucha, A. (2018). Zróżnicowanie zwycięskich projektów budżetu obywatelskiego w latach 2013-2016 w polskich miastach. Prace Geograficzne, 154, 55-70. https://doi.org/10.4467/20833113PG.18. 009.8761

Niklewicz, K. (2014). Budżety obywatelskie w kontekście wyborów samorządowych: szansa czy ryzyko? Kwartalnik Naukowy OAP UW “e-Politikon,” 11, 99-119.

No, W., \& Hsueh, L. (2020). How a participatory process with inclusive structural design allocates resources toward poor neighborhoods: The case of participatory budgeting in Seoul, South Korea. International Review of Administrative Sciences. https://doi.org/10.1177/0020852320943668

Oh, Y., Jeong, S. H., \& Shin, H. (2019). A strategy for a sustainable local government: Are participatory governments more efficient, effective, and equitable in the budget process? Sustainability, 11(19), 5312. https://doi.org/10.3390/su11195312

Olejniczak, P. (2015). Partycypacja społeczna jako podstawa społeczeństwa obywatelskiego. Prace Naukowe Wyższej Szkoty Zarzqdzania i Przedsiębiorczości, Nr, 31(1), 111-121.

Pasaogullari, N., \& Doratli, N. (2004). Measuring accessibility and utilization of public spaces in Famagusta. Cities, 21(3), 225-232. https://doi.org/10.1016/j.cities.2004.03.003

Pietrzak, E., Szczepanik, R., \& Zaorski-Sikora, Ł. (2010). Szkice z historii wychowania obywatelskiego. Przeglad Badań Edukacyjnych, 1-2, 10-11. 
Pinnington, E., Lerner, J., \& Schugurensky, D. (2009). Participatory budgeting in North America: The case of Guelph, Canada. Journal of Public Budgeting, Accounting \& Financial Management, 21(3), $455-484$.

Quality of life ranking. (2018). Polityka and AGH University of Science and Technology. https://www. polityka.pl/tygodnikpolityka/mojemiasto/1762774,1,ranking-jakosci-zycia.read. Accessed 20 Jan 2021.

Radziszewski, M. (2016). Budżet obywatelski instrumentem rozwoju kapitału społecznego. Atheneum Polskie Studia Politologiczne, 51, 131-154. https://doi.org/10.15804/athena.2016.51.08

Röcke, A. (2014). Framing citizen participation: Participatory budgeting in France. Springer.

Rokita-Poskart, D. (2016). Wojewódzkie miasta akademickie wobec zmian demograficznych w Polsce. Przeglad Nauk Stosowanych, 12, 66-76.

Rondinella, T., Segre, E., \& Zola, D. (2017). Participative processes for measuring progress: Deliberation, consultation and the role of civil society. Social Indicators Research, 130, 959-982. https:// doi.org/10.1007/s11205-015-1207-z

Rybińska, D. (2018). Instytucja budżetu obywatelskiego jako narzędzia rozwoju samorządu lokalnego. Finanse i Prawo Finansowe, 1(17), 49-65.

Schneider, S. H., \& Busse, S. (2019). Participatory budgeting in Germany-A review of empirical findings. International Journal of Public Administration, 42(3), 259-273. https://doi.org/10.1080/ 01900692.2018.1426601

Sintomer, Y., Herzberg, C., Röcke, A., \& Allegretti, G. (2012). Transnational models of citizen participation: The case of participatory budgeting. Journal of Public Deliberation, 8(2), 9.

Słomczewska, Z. (2013). Wykorzystanie narzędzi partycypacji na poziomie lokalnym do budowania partnerstwa wewnętrznego-wdrażanie budżetu obywatelskiego na przykładzie Łodzi. Studia Ekonomiczne Regionu Łódzkiego, 11, 57-70.

Sobol, A. (2017). Budżet obywatelski jako narzędzie rozwoju lokalnego. Studia Ekonomiczne, 316, $172-182$.

Sokołowski, D. (2011). Centralność większych miast Polski. Rola czynnika administracyjnego i globalizacji. Rozprawy Naukowe Instytutu Geografii i Rozwoju Regionalnego Uniwersytetu Wroctawskiego, $20,11-23$.

Solecka, I., \& Dworniczak, Ł. (2016). Obywatele kształtują krajobraz miasta. Aspekty przestrzenne i funkcjonalne inicjatyw zgłaszanych w ramach Wrocławskiego Budżetu Obywatelskiego 2013-2014. Prace Naukowe Uniwersytetu Ekonomicznego We Wrocławiu, 443, 220-231. https://doi.org/10.15611/pn. 2016.443.19

Sorychta-Wojsczyk, B. (2015). Uwarunkowania wykorzystania budżetu obywatelskiego w administracji publicznej w Polsce. Zeszyty Naukowe Politechniki Ślaskiej, 78(1928), 421-430.

Švaljek, S., Rašić Bakarić, I., \& Sumpor, M. (2019). Citizens and the city: The case for participatory budgeting in the city of Zagreb. Public Sector Economics, 43(1), 21-48. https://doi.org/10.3326/pse.43.1.4

Szaranowicz-Kusz, M. (2016). Budżet partycypacyjny w Polsce. Infos Zagadnienia Społeczno-Gospodarcze, $1,1-4$.

Szarek-Iwaniuk, P., \& Senetra, A. (2020). Access to ICT in Poland and the co-creation of urban space in the process of modern social participation in a smart city-A case study. Sustainability, 12(5), 2136. https://doi.org/10.3390/su12052136

Sześciło, D. (2015). Participatory budgeting in Poland: Quasi-referendum instead of deliberation. Hrvatska $i$ Komparativna Javna Uprava, 15(2), 373-388. https://doi.org/10.3326/pse.43.1.4

Thompson, C. W. (2002). Urban open space in the 21st century. Landscape and Urban Planning, 60(2), 59-72. https://doi.org/10.1016/S0169-2046(02)00059-2

Tolstykh, N. N. (2016). The city over space and time: the problem of the territorial identity in the context of socio-economic change. Social Psychology and Society, 7(4), 147-152. https://doi.org/10.17759/sps. 2016070410

Tykwińska-Rutkowska D., \& Glejt P., (2015) Prawna regulacja budżetu obywatelskiego a jego praktyczna realizacja - czyli o uspotecznianiu wykonywania zadań publicznych na przykładzie rozwiazań przyjętych w Trójmieście. Gdańsk: Wydawnictwo Gdańskie Studia Prawnicze.

Uddin, S., Mori, Y., \& Adhikari, P. (2019). Participatory budgeting in a local government in a vertical society: A Japanese story. International Review of Administrative Sciences, 85(3), 490-505. https://doi.org/ 10.1177/0020852317721335

UN-HABITAT. (2004). 72 Frequently Asked Questions about Participatory Budgeting Quito: AH Editorial.

Walczak, D., \& Rutkowska, A. (2017). Project rankings for participatory budget based on the fuzzy TOPSIS method. European Journal of Operational Research, 260(2), 706-714. https://doi.org/10.1016/j.ejor. 2016.12.044 
Walker, A. P. P. (2016). Self-help or public housing? Lessons from co-managed slum upgrading via participatory budget. Habitat International, 55, 58-66. https://doi.org/10.1016/j.habitatint.2016.02.005

Węglarz, B. (2018). Budżet obywatelski województwa małopolskiego. Eastern Review, 7, 189-202. https:// doi.org/10.18778/1427-9657.07.11

Wendt, J. (2007). Wymiar przestrzenny struktur i aktywności społeczeństwa obywatelskiego w Polsce. Warszawa: Wyd. IGiPZ PAN.

Wood, L., Hooper, P., Foster, S., \& Bull, F. (2017). Public green spaces and positive mental health-investigating the relationship between access, quantity and types of parks and mental wellbeing. Health \& Place, 48, 63-71. https://doi.org/10.1016/j.healthplace.2017.09.002

Publisher's Note Springer Nature remains neutral with regard to jurisdictional claims in published maps and institutional affiliations. 